\title{
'We Won't Ban Castrating Pervs Despite What Europe Might Think!': Czech Medical Sexology and the Practice of Therapeutic Castration
}

\author{
KATEŘINA LIŠKOVÁ * and ANDREA BĚLEHRADOVÁ \\ Department of Sociology, Office for Population Studies, Masaryk University, Joštova 10, \\ Brno 602 00, Czech Republic
}

\begin{abstract}
The Czech Republic holds one of the highest numbers of men labelled as sexual delinquents worldwide who have undergone the irreversible process of surgical castration - a policy that has elicited strong international criticism. Nevertheless, Czech sexology has not changed its attitude towards 'therapeutic castration', which remains widely accepted and practised. In this paper, we analyse the negotiation of expertise supporting castration and demonstrate how the changes in institutional matrices and networks of experts (Eyal 2013) have impacted the categorisation of patients and the methods of treatment. Our research shows the great importance of historical development that tied Czech sexology with the state. Indeed, Czech sexology has been profoundly institutionalised since the early 1970s. In accordance with the state politics of that era, officially named Normalisation, sexology focused on sexual deviants and began creating a treatment programme that included therapeutic castration. This practice, the aim of which is to protect society from sex offenders, has changed little since. We argue that it is the expert-state alliance that enables Czech sexologists to preserve the status quo in the treatment of sexual delinquents despite international pressure. Our research underscores the continuity in medical practice despite the regime change in 1989. With regard to previous scholarship on state-socialist Czechoslovakia, we argue that it was the medical mainstream that developed and sustained disciplining and punitive features.
\end{abstract}

Keywords: Communist Czechoslovakia, Sexological treatment, Sexology, Sexual deviance, Sexuality, Surgical castration

* Email address for correspondence: katerina@fss.muni.cz

This research was supported by the Czech Science Foundation, grant agreement number 16-10639Y. We would like to thank our anonymous reviewers for their helpful suggestions. 
'Rights group calls to ban Czech castration law' informed CNN in 2009. ${ }^{1}$ Other international media ${ }^{2}$ also covered the Czech situation where therapeutic castration has been enacted 'in some specific cases and exceptional circumstances' as a treatment method of male sexual offenders. The Czech Republic has reported one of the highest numbers of sex offenders who have undergone the irreversible surgical process of removing sex glands: between 2000 and 2016, eighty-four men were castrated. ${ }^{3}$ The castration of sex offenders is rare in contemporary Europe, making the Czech practice highly controversial.

This contentious issue was brought to the forefront for the first time in 2006 (and again, even more vigorously, in 2009) by the European Committee for the Prevention of Torture and Inhuman or Degrading Treatment or Punishment (CPT), an expert group formed by the Council of Europe. During the CPT's visits to its member state, the Czech Republic, the Committee expressed concerns about the use of therapeutic castration in the treatment of sexual deviants, and declared its invasive, irreversible and mutilating nature as unjustifiable given the current state of knowledge. Consequently, the CPT called upon the Czech authorities to ban the use of surgical castration as a treatment for sex offenders. ${ }^{4}$ However, Czech sexologists contested this criticism and set out to defend their therapeutic practice. ${ }^{5}$ Thus began the worldwide debate. On one side of the debate, the CPT and the International Association for the Treatment of Sexual Offenders (IATSO) along with other human rights organisations strongly opposed the use of castration, arguing that it is inhumane, while on the other side Czech sexologists held tight to their conviction that the practice is therapeutically necessary.

In spite of the international criticism, Czech sexology has not changed its attitude or its practice - beyond cosmetic improvements - and therapeutic castration continues to be widely accepted. Not only did the practice of castration continue, but after the main wave of criticism subsided, the Czech Republic doubled down, and in the summer of 2016 the government ratified amendments to the law 'On specific health services', which again extended, to an even wider circle of sexual deviants, the possibility of undergoing the surgery. ${ }^{6}$ The practice in the Czech Republic is all the more striking when compared with the Western countries that abandoned the surgical castration of sexual deviants decades ago. Some of which, interestingly, dropped the practice at exactly the same time that Czechoslovakia picked it up. ${ }^{7}$

${ }^{1}$ CNN, 'Rights Group Calls to Ban Czech Castration Law', 5 February 2009, http://edition.cnn.com/2009/WO RLD/europe/02/05/czech.castrate/ (accessed 18 August 2018).

${ }^{2}$ For example, there was an article from the BBC: BBC, Czechs Criticised over Castration, 5 February 2009, htt p://news.bbc.co.uk/2/hi/europe/7871783.stm (accessed 18 August 2018).

${ }_{3}^{3}$ Petr Weiss, Poruchy Sexuální Preference (Praha: Galén, 2017), 339.

${ }^{4} \mathrm{CPT}$, Report to the Czech Government on the Visit to the Czech Republic Carried out by the European Committee for the Prevention of Torture and Inhuman or Degrading Treatment or Punishment (CPT) from 27 March to 7 April 2006 and from 21 to 24 June 2006, 12 July 2007, https://rm.coe.int/1680695657 (accessed 18 August 2018); CPT, Report to the Czech Government on the Visit to the Czech Republic Carried out by the European Committee for the Prevention of Torture and Inhuman or Degrading Treatment or Punishment (CPT) from 25 March to 2 April 2008, 5 February 2009, https://rm.coe.int/1680695679 (accessed 18 August 2018).

${ }^{5}$ Czech Government, Response of the Czech Government to the Report of the European Committee for the Prevention of Torture and Inhuman or Degrading Treatment or Punishment (CPT) on Its Visit to the Czech Republic from 25 March to 2 April 2008, 5 February 2009, https://rm.coe.int/168069567b (accessed 18 August 2018).

${ }^{6}$ Ministerstvo zdravotnictví České republiky, Vláda schválila novelu zákona o specifických zdravotních službách, 7 July 2016, http://www.mzcr.cz/dokumenty/vlada-schvalila-novelu-zakona-o-specifickych-zdravotnich-sluzba ch_12280_3438_1.html (accessed 18 August 2018).

${ }^{7}$ In the Netherlands, for example, surgical castration was practised on socially perceived sexual delinquents (as such, homosexuals were targeted); however, this was abandoned by the end of the 1960s. Roland M. Bertens, 
How is it possible that the Czech Republic keeps using therapeutic castration despite international pressure? How have Czech sexologists remained convinced in the suitability and even necessity of prescribing castration? Who are the men to whom castration is prescribed and how has this category of men changed over time? In this paper, we argue that historical contingencies brought sexology close to the Czechoslovak state, and that the resulting institutional alliances from this relationship outlived the communist regime. The contemporary Czech Republic thus continues to defend the practice of therapeutic castration despite international criticism. Here, we document how sexology turned from a marginalised scholarly endeavour into a powerful field of expertise sanctioned by the state. Sexology in Czechoslovakia gained prominent status particularly during the late state's stages of socialism, during the period called 'Normalisation' by the regime's proponents. Reflecting the state priorities of that era, sexology focused on 'non-normals', ie. sexual deviants, and forged a treatment programme that came to include therapeutic castration. This sexological practice, aiming primarily to protect society from its 'dangerous' sexual others, has changed little since. We argue that it is the powerful, historically emerged expert-state alliance that makes it possible for Czech sexologists to resist international pressure and continue to practise such a questionable form of therapy.

Following the shifting matrices of expertise is central for our argument. Building on Ian Hacking's insight, we contend that 'kinds of people come into being' through the realignment of the systems of knowledge. ${ }^{8}$ As knowers deploy and redeploy knowledge about people, new descriptions of categories emerge, and with them, new kinds of people. These new kinds need to be explored and treated in new ways, which gives rise to new practices that are sanctioned and, over time, solidify into golden standards (treatment protocols, ministerial measures, laws). Thus, a once-upon-a-time new category of people gets reproduced through institutionalised forms of treatment. These 'kinds of people's' reactions to the systems of knowledge created about them are logged in, serving often to reaffirm and fine tune procedures, sometimes to disrupt them. More often than not, institutions and organisations prove to be more powerful than individual agents. However, the interactions between the idea and the people covered by that idea, set in a matrix of practices, institutions and organisations lie at the centre of our exploration. ${ }^{9}$

Indeed, it takes more than just a configuration of ideas to 'make up people'. Gil Eyal argues for the sociology of expertise that differentiates between experts (in our case, sexologists) and expertise (in our case, on therapeutic castration) where one is not reducible to the other. When studying experts, one needs to focus on groups that claim superior knowledge in a given area, struggle over jurisdictions (ie. areas of expertise), and assert their mandate to make binding pronouncements. When studying expertise, one needs to focus on 'a network linking together agents, devices, concepts, and institutional and spatial arrangements' ${ }^{10}$ Combining both - jurisdictional analysis with expertise formation analysis - 'by asking not only who controls a task and how jurisdictional boundaries are assembled but also what arrangements, devices, concepts, and other actors are necessary

\footnotetext{
'Zedendelinquentie en chirurgische castratie', Nederlands Tijdschrift voor Geneeskunde, 21 May 2018, https://w ww.ntvg.nl/artikelen/zedendelinquentie-en-chirurgische-castratie/artikelinfo (accessed 18 August 2018).

${ }^{8}$ Ian Hacking, Rewriting the Soul: Multiple Personality and the Sciences of Memory (Princeton: Princeton University Press, 1995), 6.

${ }^{9}$ Ian Hacking, The Social Construction of What? (Cambridge: Harvard University Press, 2003), 34.

${ }^{10}$ Gil Eyal, 'For a Sociology of Expertise: The Social Origins of the Autism Epidemic', American Journal of Sociology, 118, 4 (2013), 863.
} 
if an expert statement or performance is to be formulated, reproduced, and disseminated' produces insights about how 'kinds of people' emerge and how they are treated. ${ }^{11}$

Methodologically, we are inspired by Andrew Abbott's narrative programme of research. ${ }^{12}$ Thus we focus on trajectories and the ways in which they form and re-form over time. Trajectories are discernible 'patterns of succession of events' that produce social consequences, in our case, make up people (potentially) in need of castration. ${ }^{13}$ A social process understood as a 'succession of events' is distinguished by turning points: defining moments that set events on a (slightly or dramatically) different path. Trajectory can thus be viewed as 'a relatively stable set of rules governing outcomes' or, conversely, trajectories are characteristic of 'periods in which there was such a stable model'. ${ }^{14}$ Trajectories, Abbott argues, are causal (causing social consequences), and turning points produce new regimes of causality. We will thus detect the trajectories that made up different kinds of people (deviants, delinquents, etc.) and we will identify the turning points that changed the treatment of such people.

This research is based on primary sources, specifically scholarly journals ( $\check{C}$ eskoslovenská psychiatrie, Časopis lékařo českých, Československá gynekologie, Praktický lékař, Sborník lékařský), criminological articles ${ }^{15}$ (published in Kriminalistický sborník and Československá kriminalistika), conference papers, laws, (supra)governmental reports, and internet resources, as well as three interviews conducted in 2015 by one of the authors: with Filip Kapras ${ }^{16}$ and Jiři Švarc, ${ }^{17}$ both chairs of the sexological protective treatment departments at their psychiatric hospitals in the Czech Republic - Horní Beřkovice and Prague-Bohnice, respectively - and Zuzana Řerichová, ${ }^{18}$ the chief physician of the sexological department in Bohnice.

With our paper, we want to contribute to the nascent research on the social history of medicine in communist Europe. A pioneering collection of studies on psychiatry in communist Europe has recently been published that tries to fill the gap of an unexplored field. The volume, edited by Sarah Marks and Mat Savelli and titled Psychiatry in Communist Europe, explores the Communist Party's influence on both the development and the different forms of psychotherapy in East-European states. ${ }^{19}$ The assembled texts question the influence of the Communist Party on the development and forms of psychotherapy in East-European states. For example, Irina Sirotkina and Marina Kokorina's essay focuses on work therapy, which was valued by Marxism-Leninism not only for its economic value, but also as a resource of health and moral benefits. ${ }^{20}$ Contrary to prevailing beliefs in the omnipotence of anything Soviet, Mat Savelli presents the case of Yugoslavia where innovations in psychiatry were more inspired by the West than by

11 Ibid., 899.

12 Andrew Delano Abbott, Time Matters: On Theory and Method (Chicago: University of Chicago Press, 2001).

13 Ibid., 289.

14 Ibid., 291.

15 We would like to thank Lucia Moravanská for drawing our attention to criminological sources.

${ }^{16}$ Filip Kapras, interview with Andrea Bělehradová, Horní Beřkovice, 4 May 2015.

17 Jiří Švarc, interview with Andrea Bělehradová, Prague, 15 April 2015.

18 Zuzana Řeřichová, interview with Andrea Bělehradová, Prague, 15 April 2015.

${ }^{19}$ Mat Savelli and Sarah Marks (eds), Psychiatry in Communist Europe (London: Palgrave Macmillan, 2015).

${ }^{20}$ Irina Sirotkina and Marina Kokorina, 'The dialectics of labour in a psychiatric ward: Work therapy in the Kaschenko hospital', in Mat Savelli and Sarah Marks (eds), Psychiatry in Communist Europe (London: Palgrave Macmillan, 2015), 27-49. 
Pavlov. ${ }^{21}$ According to Savelli, this was possible because local professionals enjoyed a relatively high degree of independence from the USSR.

The political abuses of psychiatry in the Soviet Union are both well-known and well-documented. $^{22}$ On the contrary, the other countries of the Bloc seem to have been affected relatively little by either a Marxist-Leninist influence on psychiatric knowledge or direct state interference into psychiatric practice. ${ }^{23}$ Sarah Marks, researching Czechoslovakia, argues that 'medicine was afforded more autonomy than many other fields of intellectual endeavour'. ${ }^{24}$ However, there are researchers who argue that the socialist state exerted considerable influence over the health care system. Lily M. Hoffman analyses Czechoslovakia and asserts that the centralised organisation of the health care system diminished medical authority and its ability to define the social and economic context of its professional work. The loss of control over the organisation and reallocation of resources then had a great influence on the practice of medicine as such. On the other hand, Hoffman argues, the field of medicine had a relative degree of clinical autonomy (at least in terms of decision-making in the workplace) during the communist era because of its low political priority. $^{25}$

Pointing to the uniqueness of the role of experts in centrally planned societies, Radka Dudová has researched abortion as a medical issue in state-socialist Czechoslovakia. In her 2012 article, she argues for socialist governmentality, which 'was represented by the political rationality that determined social practices and, in effect, constituted the totalitarian communist state. The rationality behind this type of governmentality was geared towards maximising economic production, represented by heavy industry, and reproduction, manifested as (healthy and quality) population growth' ${ }^{26}$ Further, she holds that abortion was not discussed in terms of women's rights, but rather as a purely healthrelated issue. In fact, gynaecologists were the main actors in the debates about abortion and whether or not it should be legalised. Thus, she says, a specific discourse was constructed under medical leadership during the early stages of communism, and its historical continuity and stability has affected legislation and the perception of abortion up to the present day. ${ }^{27}$ Similar to our study of therapeutic castration, Dudová's research shows how powerful medical expertise was built around an issue (ie. abortion) in Czechoslovakia during the state-socialist era, and how the continuity of discourse is still capable of influencing the current situation.

Other authors researching specific areas of Czechoslovak medicine argued for strong dependence on the state, yet often analysed fringe medical practices/disciplines showcasing a large degree of autonomy. Thus, Ema Hrešanová studied perinatology

${ }^{21}$ Mat Savelli, 'Blame George Harrison: Drug use and psychiatry in communist Yugoslavia', in Mat Savelli and Sarah Marks (eds), Psychiatry in Communist Europe (London: Palgrave Macmillan, 2015), 180-95.

${ }^{22}$ Benjamin Zajicek, Scientific Psychiatry in Stalins Soviet Union: The Politics of Modern Medicine and the Struggle to Define 'Pavlovian' Psychiatry, 1939-53 (Chicago: University of Chicago, 2009); Robert van Voren, Cold War in Psychiatry: Human Factors, Secret Actors (New York: Rodopi, 2010).

23 Savelli and Marks, op. cit. (note 19).

${ }^{24}$ Sarah Marks, 'Ecology, humanism and mental health in communist Czechoslovakia', in Mat Savelli and Sarah Marks (eds), Psychiatry in Communist Europe (London: Palgrave Macmillan, 2015), 135.

${ }^{25}$ Lily M. Hoffman, 'Professional Autonomy Reconsidered: The Case of Medicine under State Socialism', Comparative Studies in Society and History, 39, 2 (2012), 346-72.

${ }^{26}$ Radka Dudová, 'Regulation of Abortion as State-Socialist Governmentality: The Case of Czechoslovakia', Politics and Gender, 8, 1 (2012), 140.

${ }^{27}$ Radka Dudová, 'The Framing of Abortion in the Czech Republic: How the Continuity of Discourse Prevents Institutional Change', Czech Sociological Review, 46, 6 (2010), 945-75. 
and obstetrics to point out its divergent development from the West. She focused on the psychoprophylactic method of helping women prepare for a painless childbirth, a practice which was ushered in in Czechoslovakia in the early 1950s as 'Soviet science's gift to women'. ${ }^{28}$ With regard to childbirth and maternity care, Hrešanová shows how fundamentally political and cultural factors can influence medical science and practices. She highlights the importance of analysing continuity and discontinuity across different societal and historical contexts to find out how 'deeply cultured a phenomenon obstetrics truly is'. ${ }^{29}$ In analysing the case study of a maternity hospital in Ostrov nad Ohř́, Hrešanová pointed out that mainstream obstetrics strove to maintain control over women giving birth while the Ostrov hospital (where ostrov literally means 'island') created an island "promot[ing] an individualised approach to birth and newborn care ...call[ing] for the provision of support and basic comforts to laboring mothers and an end to the assembly-line techniques so pervasive in socialist maternity wards' ${ }^{30}$ Thus while studying medical disciplines central to state-socialist healthcare, such as perinatology and obstetrics, Hrešanová focused on a fringe practice of psychoprophylaxis before child delivery or a unique maternity hospital to document diversions from the medical mainstream. Michaela Appeltová analysed the discourse of obesitology, a medical branch of endocrinology, and argued for the 'Communist Party's dependence on expert knowledge [while] an opinion-making (bio)power centre emerged that stood, to an extent, outside of party structures'. ${ }^{31}$ Further, Appeltová shows how this rather fringe medical discourse penetrated the public and the extent to which it continued to form the post1989 understanding of 'the fat body'. Adéla Gjuričová documented the developments of late state-socialist psychotherapy, a border discipline that stood outside of medicine. In contrast to medical psychiatry, through which 'the Czechoslovak socialist state applied a strong and, to a large extent, unified understanding' of the human psyche, ${ }^{32}$ psychotherapy stood below the resolution capacity of the state, a situation enabling its practitioners to sometimes 'use state resources for unofficial means', ${ }^{33}$ which in turn made possible the development of non-traditional treatment methods (such as intensive group therapies that resembled communal living, in which therapists participated alongside their patients). We can conclude that while countries like Czechoslovakia did not experience such strong state oversight as psychiatry did in the Soviet Union, the interplay between the state and medical expertise shaped knowledge, diagnoses and treatment: in our case, for sexual deviants. We can also see that 1989 did not cause a rupture in medical views and practices, which continued rather smoothly into the subsequent years and even decades.

For our analysis of surgical castration, we need to understand the developments in sexology, a discipline that has existed in Czechoslovakia since 1921 and continued uninterrupted after 1945 (see below). We will show how Czechoslovak sexology became interested in deviants and that these deviants were not homosexuals. In fact, Jan

${ }^{28}$ Ema Hrešanová, 'The Psychoprophylactic Method of Painless Childbirth in Socialist Czechoslovakia: From State Propaganda to Activism of Enthusiasts', Medical History, 60, 4 (2016), 534-56.

29 Ibid., 556.

${ }^{30}$ Ema Hrešanová, 'The Island of Alternatives: Power, Medical Science and "Gentle Birthing" in Socialist Czechoslovakia', Journal of the History of Medicine and Allied Sciences, 73, 1 (2018), 95.

${ }^{31}$ Michaela Appeltová, “Tlusté” tělo v normalizačním Československu: Povinná zdatnost a gender v kampani proti obezitě', Gender, rovné př́ležitosti, výzkum, 17, 1 (2016), 19.

32 Adéla Gjuričová, 'Bohatství pod neviditelným pláštěm? K psychoterapii v Československu po roce 1968', Soudobé dějiny, 24, 3 (2017), 314.

33 Ibid., 323. 
Seidl presents evidence about the crucial role sexologists played in decriminalising homosexuality. ${ }^{34}$ Before its legalisation in 1961, the sexologist Kurt Freund was researching homosexuality in Prague; he invented a phallometric test in order to scientifically diagnose male homosexuality. Tom Waidzunas and Steven Epstein saw the device as a kind of 'truthing technology' that would reflect male sexual desire. ${ }^{35}$ With its declared ability to measure non/normality, phallometry played an important role in the process of 'making up people'. Yet, these people were not seen as in need of rectifying. As Věra Sokolová demonstrates, sexologists, particularly during the late stages of state socialism, protected and sheltered homosexuals from state intrusion. ${ }^{36}$ In any case, Czechoslovak sexology was an important 'psy-ence, ${ }^{37}$ that became instrumental in shaping people's gendered and sexual selves according to the regime's changing priorities. ${ }^{38}$ We will exemplify this in the case of men who were labelled sexual deviants and/or delinquents.

Before we begin, we need to explain the terms that describe the kind(s) of people we are focusing on. Because, indeed, '[n]ames organize our thoughts'. ${ }^{39}$ And so do the thoughts of contemporaneous experts that produce the names that have requisite power in medical diagnosis and treatment, as well as in legal adjudication. Since we are tracing the history of therapeutic castration in the Czech Republic, we use the very same terminology that the experts (sexologists, criminologists, etc.) used during our period of inquiry. Thus, we use words that might ring offensive to a contemporary ear. Yet labels such as deviant, sexual delinquent, sexual aggressor, or sex offender trigger 'sharp differences in the moral images and ethical responses' we may have, terms that were utilised to capture changing kinds of people whom experts approached with varying types of treatment. ${ }^{40}$ The treatments were custom-made for each 'kind', with labels sometimes emerging before a specific treatment was even formulated. Labels in retrospect legitimise treatments, the clear example of which, as our title suggests, is 'perv' which was employed to sanction an embattled form of treatment, wholesale. In any case, our aim is to be historically accurate.

\section{The Early Trajectory in Treating Sexual Deviants}

Medical sexology has a long history in the Czech Republic. The Institute for Sexual Pathology was founded as part of Charles University’s Medical School in 1921, gaining

\footnotetext{
34 Jan Seidl, Od žaláře k oltáři: Emancipace homosexuality v českých zemích od roku 1867 do současnosti (Brno: Host, 2012), 265-95.

35 Tom Waidzunas and Steven Epstein, “For Men Arousal Is Orientation”: Bodily Truthing, Technosexual Scripts and the Materialization of Sexualities through the Phallometric Test', Social Studies of Science, 45, 2 (2015), 187-213.

36 Věra Sokolová, 'State approaches to homosexuality and non-heterosexual lives in Czechoslovakia during state socialism', in Hana Havelková and Libora Oates-Indruchová (eds), The Politics of Gender Culture under State Socialism: An Expropriated Voice (New York: Routledge, 2014), 82-108.

${ }^{37}$ See Nikolas Rose, 'Engineering the Human Soul: Analyzing Psychological Expertise', Science in Context, 5, 2 (1992), 351-69; Nikolas Rose, Inventing our Selves: Psychology, Power, and Personhood (Cambridge: Cambridge University Press, 1996).

${ }^{38}$ Kateřina Lišková, "Now You See Them, Now You Don't”: Sexual Deviants and Sexological Expertise in Communist Czechoslovakia', History of the Human Sciences, 29, 1 (2016), 49-74; Kateřina Lišková, 'Sex under Socialism: From Emancipation of Women to Normalized Families in Czechoslovakia', Sexualities, 19, 1-2 (2016), 211-35; Kateřina Lišková, Sexual Liberation, Socialist Style: Communist Czechoslovakia and the Science of Desire, 1945-89 (Cambridge: Cambridge University Press, 2018).

${ }^{39}$ Hacking, op. cit. (note 9), 17.

${ }^{40}$ Gil Eyal et al., The Autism Matrix: The Social Origins of the Autism Epidemic (Cambridge: Polity Press, 2010), 6 .
} 
world renown as the first university-based centre for sexual science. ${ }^{41}$ However, its real development can be dated to the period after the Second World War, in the early years of state socialism, when a small circle of sexologists coming from various medical disciplines got together. The history of the Sexological Institute, as it was re-named in 1950, has been an uninterrupted one ever since. ${ }^{42}$ Strikingly, for a state-socialist country, an institute researching sexuality was not only present from the very inception of the regime but, moreover, it remained in operation despite various purges and regime shifts that afflicted communist rule across the Eastern Bloc. Within the Sexological Institute, the same group of doctors worked for the entirety of the forty years of state socialism and beyond, their ranks growing as time went on. ${ }^{43}$

In the 1950s, sexologists focused on virtually any area of sexuality except for 'aberrations'. ${ }^{44}$ Doctors were preoccupied with fertility problems and various physiological problems relating to marital sexuality. Indeed, the Institute changed its name for a while to the Laboratory for Infertility in order to both express its main business and fend off worries about its 'prurient' area of interest. ${ }^{45}$ As one of the authors shows elsewhere, sexologists in the long 1950 s dealt with aberrations only in passing. ${ }^{46}$ Moreover, they were rarely invited to court to present their forensic evaluations. If any experts were called upon to give testimonies, they tended to be psychiatrists. Needless to say, sexologists did not always see eye to eye with psychiatrists and often considered their conclusions illinformed. ${ }^{47}$ In the rare cases when sexologists testified, the courts ruled against their expert opinions. ${ }^{48}$ While sexologists discussed potential benefits of court-ordered treatment, no specialised facilities existed and the only place outside of prison where a convicted man could have been sent was a psychiatric hospital. However, psychiatric facilities were not at all equipped to treat sexual afflictions and confining such inmates posed problems of its own. Sexologists complained throughout the decade: at the beginning they lamented the 'inadequate organisation of medical care', and 'rather weaker treatment results'; ;9 towards the end, they admitted that there was a 'poor therapeutic arsenal' in treating sexual deviants. ${ }^{50}$ This situation lasted until about the mid-1960s. ${ }^{51}$

During this early phase, a trajectory of dealing with a man who committed a sexual offence was either characterised by rareness (few such men came to the sexological purview) or haphazardness (no systematic treatment was spelt out, let alone practised), and was plagued by jurisdictional struggles between two forms of expertise - sexological and psychiatric.

\footnotetext{
41 Václav Urbánek and Jaroslava Pondělíčková-Mašlová, 'Josef Hynie (1900-89) - Sto let od narození zakladatele československé sexuologie', Sborník lékařský, 101, 2 (2000), 173-84.

42 ; Jan Dobiáš, 'K sedmdesátce prof. MUDr. Josefa Hynieho, DrSc.', Československá psychiatrie, 66, 3 (1970), 191-2 Josef Hynie, Československá sexuologie po osvobození, Časopis lékařu českých, 114, 24 (1975), 721-3.

${ }^{43}$ For more on the history of sexology in Czechoslovakia, see Lišková, Sexual Liberation, op. cit. (note 38).

${ }^{44}$ Czechoslovak sexologists in the 1950s explored the classical 'aberration', homosexuality, in laboratories and concluded it was an incurable condition. This finding led them to call for its decriminalisation, which was codified in 1961, earlier than in Western countries. Seidl, op. cit. (note 34).

45 Dobiáš, op. cit. (note 42).

${ }^{46}$ Lišková, 'Now You See Them', op. cit. (note 38).

${ }^{47}$ Karel Nedoma and Kurt Freund, 'Otázka př́icetnosti a nápravných opatření u sexuálních delikventů', Československá psychiatrie, 55, 4 (1959), 264-9.

${ }^{48}$ Karel Nedoma, 'Nový trestní zákon a trestné činy lidí s odchylnými sexuálními tendencemi', Praktický lékar̆, 33, 14 (1953), 316-8.

${ }^{49}$ Ibid., 318.

${ }^{50}$ Nedoma and Freund, op. cit. (note 47), 266.

51 Josef Hynie, 'Problémy sexuologické péče v ČSSR', Československá gynekologie, 31, 8 (1966), 561-2.
} 


\section{Turning Point 1: Three Innovations in Treatment Formulated in the 1960s}

While the position of sexology had been rather uncertain and fragile in the 1950s, the situation began to change slowly during the following decade. Thus, the gradual rise in the importance of Czechoslovak sexology in the 1960s coincided with the establishment of various approaches to treating sexual deviants. In the first half of the decade, the Sexological Institute in Prague examined about 5000 new patients every year and such an unusual strain triggered the need for appropriate specialists with sexological knowledge. ${ }^{52}$ As a result, a sexological course for practising psychiatrists, gynaecologists, urologists and dermatho-venereologists was created and sexological training subsequently became part of the post-graduate studies in psychiatry. ${ }^{53}$ Sexology intensified its cooperation with psychiatry, and what was a previously scattered field of expertise - between sexologists and psychiatrists, both in clinical practice and in forensic evaluations - began to link. This helped to consolidate sexology as a form of expertise, contributed to its development and allowed the sexologist Jiří Mellan to state proudly in 1970: 'The last ten years were ... in the development of Czechoslovak sexology unprecedentedly fortunate. ${ }^{54}$ The advancement he praised included the therapy for sexual deviations.

In 1960, a criminological-psychiatric seminar took place that was devoted to the forensic issues of sexual deviations: psychiatrists alongside sexologists discussed the options for treating sexual deviants. ${ }^{55}$ This discussion foreshadowed the atmosphere of the 1960s, during which three avenues of treatment (1. hormonal downturn complete with psychotherapy; 2. castration; and 3. protective treatment) were tested, two of which were implemented: the first one became the leading practice of the 1960s, the second one was legalised in 1966; the third one was institutionalised in the following decade (see the following section).

The first important treatment innovation, hormonal downturn accompanied by psychotherapy, was brought about by the sexologist Karel Nedoma ${ }^{56}$ and continued to be a basis for therapy for years to come. Nedoma, inspired by the positive effects of administering oestrogen to sex offenders abroad, ${ }^{57}$ published a text in which he extolled hormonal castration. He warned that surgical castration causes 'serious anatomical and functional deformation to the organism and [brings about] an irreversible effect which dissuades from the general use of this method' ${ }^{58}$ Thus, in 1964, a leading specialist on sexual deviance argued for a temporary method of hormonal downturn (achieved by administering female sex hormones) because it is reversible, and so the normal

\footnotetext{
52 Ibid., 561; Vladimír Barták, 'Koncepce sexuologie a současný stav sexuologické preventivně léčebné péče v České socialistické republice', Časopis lékař̆u českých, 116, 29-30 (1977), 912-14.

53 Vladimír Barták, ‘Československá sexuologie a dvacet let rozvoje Sexuologického ústavu', Časopis lékařu českých, 104, 20 (1965), 529-30; Barták, ibid.

54 Jiří Mellan, ‘Československá sexuologie 1961-70', Časopis lékařu českých, 109, 26-7 (1970), 585.

55 Jiří Roubíček, 'Zpráva o odborné činnosti, sjezdech a pracovních schůzích v roce 1960', Československá psychiatrie, 57, 1 (1961), 133-9.

56 Karel Nedoma, 'Adaptační léčba sexuálních deviací u mužů’, Československá psychiatrie, 60, 4 (1964), 234-9.

${ }^{57}$ Nedoma quoted papers from the Journal of American Medical Association, the Journal of Nervous and Mental Disease and the Lancet published during the 1940s. None of the authors was from the USSR or an Eastern Bloc country. Similar to Mat Savelli, op. cit. (note 21), who showed how psychiatry in Yugoslavia was inspired by the West more than by Pavlov, we identified the same trend in the first half of the 1960s in Czechoslovakia. The therapeutic innovations were designed during that time and, similar to Yugoslavia, one of them - proposed by Nedoma - was inspired purely by Western methods of the treatment. However, the treatment took on a different direction during the era of Normalisation.

58 Nedoma, 'Adaptační léčba', op. cit. (note 56), 234.
} 
physiological functions of the male body (such as the ability to produce sperm) are able to resume after the treatment is ended. In the same breath, he warned against using the permanent method: surgical castration. ${ }^{59}$

Based on his findings, Nedoma designed a two-stage form of treatment for sexual deviation. He said the first stage (lasting several months) should 'induce a deep downturn of androgenic activity' after a large amount of oestrogen has been administered. The goal in the second stage was to offset the negative side-effects of the female hormones while maintaining a systematic sexual downturn which would be "sufficient for [the] permanent social adaptation' of the sexual deviant. ${ }^{60}$ Thus, the amount of oestrogen was administered in decreasing doses. Importantly, Nedoma began highlighting the psychotherapeutic part of the treatment that constituted a crucial part of the second stage. After evaluating his research findings, he concluded: 'Even a very deep hormonal downturn is not sufficient for the social adaptation [of the sexual deviant] without a concurrent psychotherapy that functions as a re-education of a patient in a deviant psychological state. ${ }^{61}$ Thus, from the 1960s, sexologists did not cure just the patient's body by using hormones to temper its physiological manifestations, but also his mind when they tried to attain 'a conscious repression of deviant sexual fantasies and interests while developing some socially unobjectionable sexual activities'. ${ }^{62}$

So, a concurrent psychotherapy was brought to the fore. Such therapy had, according to the experts, just one important weakness - in order for it to be successful, the sex offender had to open his mind up to the change. Thus, 'a deep and fixed enough' motivation and active effort to be cured on the part of the patient was crucial. ${ }^{63}$ However, not everyone proved to be sufficiently motivated to truly try and change his (sexual) behaviour. ${ }^{64}$ This might have been why it did not take too long for Nedoma's colleagues to begin considering a more permanent method of treatment that did not depend on the will and moral determination of the sex offender in order for them to be 'cured'.

Consequently, the second treatment innovation was introduced: the method of surgically removing the testicles, a.k.a. therapeutic castration. Not a lot of information can be found about the first instances in which the method was used. What we know for sure is that the surgery had been performed before its legalisation in $1966 .{ }^{65}$ Moreover, we can merely

${ }^{59}$ Ibid.

${ }^{60}$ Ibid., 234-5.

${ }^{61}$ Ibid., 238.

62 Ibid., 235.

${ }^{63}$ Ibid., 238.

${ }^{64} \mathrm{Ibid}$.

${ }^{65}$ Lumír Tauš and Lucie Sušická, 'Pětileté sledování pěti sexuálních deviantů po terapeutickém zákroku', Československá psychiatrie, 69, 1 (1973), 51. By the same law, the sterilisation of women was legalised and, like castration, further specified in the 1972 directive of the Ministry of Health. 'Provádění sterilizace', Věstník Ministerstva zdravotnictví České socialistické republiky, 20, 1-2 (1972), 1-3. Although the written law was ethnic-neutral, its implementation into practice (mostly by local doctors and social workers) was racially biased. Many Roma women were thus coercively sterilised on the basis of this law. Věra Sokolová, Cultural Politics of Ethnicity: Discourses on Roma in Communist Czechoslovakia (Stuttgart: ibidem-Verlag, 2008). As in the case of castration, we do not have decisive statistics available about the number of sterilised women during socialism in Czechoslovakia. However, Otakar Motejl, former Czech ombudsman, stated in 2009 that it was about 90,000 Roma women. Claude Cahn, 'Coercive sterilisation of Romani women in the Czech and Slovak Republics', in Claude Cahn, Human Rights, State Sovereignty and Medical Ethics: Examining Struggles Around Coercive Sterilisation of Romani Women (Leiden: Martinus Nijhoff Publishers, 2014), 40-105. A closer comparison of both practices is beyond the scope of this study, but for more information on the sterilisation of Roma women, see ibid.; Sokolová, Cultural Politics of Ethnicity; Kristína Čajkovičová, 'Shifting to the "Gadžo question": The Role of Racialized Sexuality in the Biopolitical Consolidation of Czechoslovak Collectivity' (unpublished MA thesis: Central European University, 2017). 
guess how many offenders underwent the procedure and how it worked because there were no scholarly articles written about it at the time. Indeed, it seems it received no special attention. Ironically, the very permanent method of testicle removal came into practice at the same time as Nedoma was exhorting the reversible method of hormonal downturn.

Regarding the third form of treatment, in the latter half of the 1960s, some experts, especially psychiatrists, stressed that 'a special psychiatric ward for the protective treatment of delinquent sexual deviants' should be founded with the perspective 'to move them from punishment to protective treatment'. ${ }^{66}$ However, their wishes to establish a special medical programme devoted to sexual deviants would not be fulfilled until the following decade.

By the end of the 1960s, sexologists had not yet arrived at a unified solution to the problem of sexual deviance. Rather, isolated attempts at a cure coexisted as both methods - reversible but also irreversible - were being employed. ${ }^{67}$ During the decade, only few experts were licenced, and they lacked sanctioned treatment procedures, resources and, in fact, a sharp focus on the issue of sexual deviance. That was going to change in the following decade.

\section{Turning Point 2: The Preference for Castration in the Wake of the Failed Prague Spring}

It would be curious to see which direction sexological treatment would have taken and which path from the three innovations of the 1960s would have been travelled, had it not been for events in the year 1968. In the spring of that year, Czechoslovak society clamoured for political changes under the banner of 'socialism with a human face'. In the summer of that year, Soviet-led tanks rolled over people's hopes and the period of 'normalisation of conditions' ensued. Communist elites sought law and order, the emblem of which became the re-traditionalised nuclear family. Those who did not fit into this mould could be targeted as suspicious and labelled as deviant. ${ }^{68}$ Ranks of men diagnosed as sexually deviant grew and with them the need for methodical treatment and containment so that the 'deviants' were no longer a danger and could potentially re-join society as permanently 'cured'.

\footnotetext{
66 Jaromír Rubeš, 'Psychiatrické služby v nápravné péči o delikventní jedince (cílová perspektiva)', Československá psychiatrie, 63, 5 (1967), 353.

${ }^{67}$ In the second half of the 1960 s, Czech sexologists also briefly experimented with psychosurgical stereotactic operations on the brains of sexual deviants. The method was based on the premise that there is a distinct centre of sexual activity in the brain and, in the case of sexual deviants, there are specific qualitative changes that can be detected and then surgically modified. They assumed, then, that such medical intervention would result not only in the decrease of the deviants' sex drive, but also (in comparison to surgical castration) in the correction and regulation of the deviant desires. A handful of trial operations were thus performed in Havlíčkův Brod between 1964-67. Jozef Pogády and Pavel Nádvorník, 'Psychochirurgia', Československá psychiatrie, 78, 1 (1982), 3-16. However, the method did not gain popularity amongst Czech sexologists because of the uncertain results and the considerable negative side-effects. Antonín Brzek and L. Ondruch, 'Možnost chirurgické léčby sexuálního delikventa v průběhu trestního řízení', Československá psychiatrie, 78, 6 (1982), 371-4. Nevertheless, the stereotactic method found its supporters in the Slovak part of the country. The Slovak experts thus established a stereotactic ward in Pezinok in 1971 'which gradually took over the nationwide task of surgically treating the disorders of the mentally ill': Pogády and Nádvorník, ibid.. In spite of their attempts, stereotactic operations have never been broadly used because 'the risk of the deterioration of other brain functions, even the death rate was ... too high, and its effect on the relapse of the patients very inconclusive': Weiss, op. cit. (note 3), 349. Interestingly, the case of stereotactic operations is probably the only example of Czech and Slovak sexological expertise slightly differing from one another.

${ }^{68}$ Lišková, 'Now You See Them', op. cit. (note 38); Lišková, Sexual Liberation, op. cit. (note 38).
} 
A man who was sentenced for a criminal sexual act was imprisoned, unless he was found insane (nepríčetný), ie. if he 'could not recognize the dangerousness of his conduct or could not control it' due to his deviant sexual urges. ${ }^{69}$ In such a case, he was also sentenced to a general protective treatment. Yet, the psychiatric hospitals where sex offenders ended up lacked treatment protocols and, as a consequence, such inmates 'might not exhibit their (problematic) sexual traits, in which case they would be released and return to society unchanged, in even more heightened sexual tension'. ${ }^{70}$ Their dangerousness would not only not decrease, it might even grow. Thus, doctors called for establishing specialised treatment facilities.

The first ward for sexological protective treatment was founded in the mid-1970s. This development coincided with the mass opening of regional sexological centres across the country that were to serve the general population with their various sexual ailments. Yet, medical doctors practising in these regional centres soon noticed that up to $10 \%$ of their patients were referred by the police and that $7 \%$ of all their cases were diagnosed as deviant. ${ }^{71}$ This represented a $100 \%$ increase compared to the situation a dozen or so years earlier in the 1950 s, when a mere $4 \%$ of patients were diagnosed with 'aberrations', and court cases had occupied sexologists in only $1 \%$ of all cases. ${ }^{72}$ Yet that figure had already doubled and continued to rise. At the turn of 1976/77, the number of patients rose by a third within three months. ${ }^{73}$ Deviants were all of a sudden treated in regional sexological clinics where there had previously been no such patients whatsoever, ${ }^{74}$ while clinics in other regions reported dealing with eight times the amount of deviants when compared with the preceding decade. ${ }^{75}$ Men transgressing sexual norms were all of a sudden everywhere.

A new description emerged and with it a new kind of person: a recidivist sexual aggressor (recidivujicí sexuální agresor). He (because it was always a 'he') was heterosexual, yet failed with women. Specifically, he could not master the social part of an interaction with a woman. When such a man approached a woman, what ensued resembled an attack more than courtship. Yet it was not violence that such a man sought, aggression was not arousing to him. He just inadvertently ended up acting violently and could not break the repeating pattern. Sexologists described one such man in the following way:

'He was shy with girls, he did not know how to chat (bavit se), he never struck up a relationship. ... During clinical examination, the most prominent feature was his utter lack of sexual information, stemming apparently from his poor interpersonal relationships.... [In his erotic fantasies] he never imagined intercourse, with which he had no experience; the first information about sexual intercourse was from the experts during his previous examinations. ${ }^{76}$

\footnotetext{
${ }^{69}$ Lumír Tauš, 'Postavení sexuálních deviantů v naší společnosti z hlediska psychiatra', Československá kriminalistika, 3, 4 (1970), 280.

70 Ibid., 281.

${ }^{71}$ Barták, op. cit. (note 52).

72 Hynie, op. cit. (note 42).

73 Barták, op. cit. (note 52), 914.

74 Karel Tabarka, 'Vývoj a současný stav sexuologické péče v rámci sexuologického ordinariátu při psychiatrické klinice v Olomouci', Časopis lékařu českých, 116, 29-30 (1977), 917.

75 Erich Sýkora, 'Zajištění sexuologické péče v Severomoravském kraji', Časopis lékař̃o českých, 116, 29-30 (1977), 919.

${ }^{76}$ Karel Nedoma, 'Recidivující sexuální agresor v posudku psychiatrickém a sexuologickém', Československá psychiatrie, 68, 5 (1972), 309.
} 
This man and his ilk also featured, besides sparse experience with women, a lower level of intelligence combined with heightened sexual excitability, yet they were fully responsible for their actions and the courts tended to conclude that such men were fully criminally liable. In any case, the eyes of the doctors, something was awry with such men.

Sexologists tended to argue that men labelled as recidivist sexual aggressors were not only to be sent to prison. While judges saw them as sane and thus criminally responsible, sexologists diagnosed them as ill and in need of treatment. A special sexological protective treatment facility opened in the mid-1970s as part of a psychiatric hospital in Horní Beřkovice; it was founded as a result of the directives (směrnice o ochranné léčbě) drafted by sexologists Karel Nedoma and Jiří Mellan and issued by the Ministry of Health in 1974. ${ }^{77}$ This ward was truly foundational: not only was it the first of its kind and all the methods of treatment were tested and established there, it continues to be referred to as the cradle of Czech(oslovak) therapy for sex offenders. Indeed, the sexological ward in Horní Beřkovice exists to this day.

Men under sexological protective treatment (sexuologická ochranná léčba, abbreviated as SOL) were not so much deviants as they were 'sexual delinquents in the broadest sense' ${ }^{78}$ Moreover, most of them did not recognise they had a problem. As sexologists noted:

only $25 \%$ of the patients recognised the legitimacy of SOL and were willing to be cured. Another $25 \%$ admitted sexual deviance but they blamed their environment and did not recognise the need for treatment. A full $50 \%$ of the patients were completely uncritical, denied deviance and the crime. ${ }^{79}$

Another sexologist lamented: 'The ratio of delinquents who are in denial (bez náhledu) or uncooperative is increasing. ${ }^{80}$ The treatment then consisted of two objectives: to explain to the patients that they harmed society, and to teach them how to treat women. In order to fulfil the first objective, patients underwent individual and group therapy, kept a diary and followed a 'firmly structured' regimen complete with a 'scoring system with a set system of rewards and penalties' ${ }^{81}$ To meet the second objective, the patients listened to lectures delivered by doctors, watched TV together and twice a month visited dances to which female patients of the psychiatric hospital were invited. In other words, the SOL patients were re-socialised into 'normal heterosexuality' as it was supposed to be practised in 1970s Czechoslovakia. As the doctors working in the ward wrote: 'The goal of the complex adaptation therapy is not just preventing recidivism but also the re-construction, re-socialisation and integration of a patient's personality. ${ }^{82}$

The sexual delinquent was to be profoundly changed - made into a normal person who is integrated into wider society. If an inmate developed a positive relationship to the treatment, showed he understood his problem and internalised the threat of relapse, then he could be released from institutional confinement. After that, he would follow outpatient therapy which in some risky cases included medication aimed at inhibiting his sexual desire.

\footnotetext{
77 'Dispenzární péče o sexuální devianty', Věstník Ministerstva zdravotnictví, 39, 22-4 (1974), 236-7.

78 Viola Singer et al., 'Režimové oddělení pro léčbu sexuálních delikventů', Československá psychiatrie, 73, 1 (1977), 41.

79 Ibid., 42.

${ }^{80}$ Barták, op. cit. (note 52), 914.

${ }^{81}$ Singer et al., op. cit. (note 78), 43.

${ }^{82}$ Slavomil Hubálek and Jana Zimanová, 'Psychoterapie sexuálních deviantů', Sborník prací přednesených na vědecko-pracovní schůzi České sexuologické společnosti, Opava-červen (Ostrava: KÚNZ, 1978).
} 
Some hormone inhibitors and tranquillisers were already used as part of SOL treatment within these early sexological wards. However, hormonal therapy was expensive, difficult to obtain, reversible and, as such, particularly dependent on the delinquent's discipline and regular use ${ }^{83}$ which proved problematic upon the release of SOL patients from the sexological facilities. Doctors became convinced that truly dangerous sex offenders were generally unwilling or unable to cooperate in controlling their sexual urges. Invoking the safety of society, doctors made it virtually impossible for the 'really dangerous' offenders to be discharged from protective treatment. In the eyes of the sexologists, the only safe way to treat these men was therapeutic castration. Indeed, out of the 237 patients treated during the years 1976-1983, twenty-nine of them (ie. 12.2\%) were castrated ${ }^{84}$ Ultimately, the technique was used more and more often.

At the beginning of the 1970s there had been a consensus that castration should only be performed in 'absolutely exceptional cases of highly socially dangerous sex delinquents' after they themselves requested it in writing and an expert committee approved the request. ${ }^{85}$ Such a requirement was seen as a guarantee of the patient's free will and the confirmation of a genuine medical need from the perspective of the experts. Yet, during the 1970s, experts - criminologists and psychiatrists - were already calling for castration as the ultimate treatment. ${ }^{86}$ For example, a man who murdered two women was sent to psychiatric treatment for his sadistic behaviour, and a criminologist had already opined during the sentencing that '[i]t is beyond imagination to think that in the future, his treatment would end without castration'. ${ }^{87}$ Similarly, a criminologist together with a psychiatrist doubted it would ever be possible to release a particular young man with severely decreased intelligence who killed a four-year-old girl after sexually molesting her. 'There is no guarantee that even if the patient follows doctors' orders [upon release], he will not re-offend in the future. ${ }^{88}$ In his case, too, castration was suggested as the only solution. Another young man in his twenties met an attractive woman at a village dance, offered to escort her home and during the walk attempted to kiss her. Her refusal confused and enraged him and he dragged her into a field where he attempted to rape her. While he tried to silence her calls for help, he accidentally strangled her. He was sentenced to psychiatric treatment for his 'deviant sexual programming in which he prefers females [as] objects more or less unknown [to him] . . which might prove life-threatening to them' ${ }^{89}$ Psychiatrists stressed the importance of protective treatment 'resulting in castration'. 90

\footnotetext{
83 Jaroslav Zvěřina and Jiří Mellan, , Československá psychiatrie, 80, 1 (1984), 50-6; Želmíra Herrová cited in Eliška Bártová, Proč se v Česku kastruje? Je to levnějš̌́, 21 May 2009, https://zpravy.aktualne.cz/domaci/proc-s e-v-cesku-kastruje-je-to-levnejsi/r i i:article:637904/ (accessed 18 August 2018).

84 Jana Zimanová et al., 'Některé současné názory na terapeutickou kastraci sexuálních delikventů a naše zkušenosti', Československá psychiatrie, 84, 3 (1988), 175.

85 Jan Raboch and Karel Nedoma, 'Indikace testikulární pulpektomie u sexuálních delikventů', Československá psychiatrie, 66, 3 (1970), 152-7.

${ }^{86}$ Different kinds of expertise - sexological, psychiatric and criminological - intersect on the issue of sexual delinquents. Indeed, these groups of experts broadly cooperated and agreed that there was a need for specialised treatment (in many cases pointing to castration). Lucia Moravanská analyses Czechoslovak criminology in her paper 'Towards a Psychopathology of Murder: Spousal Murder in Czechoslovak Criminological Discourse after 1968' (manuscript).

${ }^{87}$ Zdeněk Bažant, 'Vražda z vilnosti', Kriminalistický sborník, 18, 4 (1974), 238.

88 Emil Hesek and Zdeněk Bašný, 'Sexuální deviace a problémy ochranného léčení', Kriminalistický sborník, 19, 6 (1975), 326.

89 Jan Krtička, 'Vražda nebo znásilnění se smrtelným následkem?’, Kriminalistický sborník, 20, 1 (1976), 39.

90 Ibid.
} 
By the mid-1980s, it became clear to doctors that they were dealing with two groups of sexual offenders: deviants and aggressors; and these two groups were like night and day. Sexologists found almost an inverse correlation between a diversity of clinical symptoms and widely developed fantasy on the one hand, and real danger to society on the other. ${ }^{91}$ In other words, deviants were seen as less dangerous than unpredictable sexual aggressors. A blurry and all-encompassing category of 'sexual delinquents' morphed into a dangerously sounding diagnosis of 'pathological sexual aggression' ${ }^{92}$ that further helped legitimise the use of such final methods as surgical castration.

\section{The Long Trajectory of Institutionalised Treatment and Castration Since the 1980s and Beyond}

While the 1970s was a period of breakthrough changes in the treatment of sexual deviations, the 1980s can mostly be described as a time of a stabilisation of the therapeutic practice. During that time, new sexological wards specialising in therapy for sexual deviants/delinquents opened in several psychiatric hospitals all over the country. ${ }^{93}$ In order to ensure a uniform system of treatment for deviant/delinquent inmates at these new wards, the 'Methodical List no. 1/1985: On the medical procedures for protective treatment of sexual deviants' was established. ${ }^{94}$ This regulation summed up the therapeutic knowledge acquired over the previous decade. Thus, a complex regime of protective treatment that had been developed during the second half of the 1970s in Horní Beřkovice, was implemented in every sexological ward in the country. The Methodical List also specified that SOL was to be ordered by the court based on the recommendation of forensic experts from the fields of psychiatry and sexology. Indeed, SOL was to be court-ordered in cases in which 'a disorder of sexual behaviour ... substantially influenced the individual in committing the crime' ${ }^{95}$ As a result, SOL could potentially be ordered for anyone who committed a sexual offence of any kind, if a forensic expert suggested it. ${ }^{96}$ Strikingly, the directive was not officially revised until after repeated visits by European experts in the new millennium.

\footnotetext{
${ }^{91}$ Petr Weiss and Jana Zimanová, 'Deviantní a nedeviantní sexuální delikventi', Časopis lékařu českých, 124, 20 (1985), 622-5; Petr Weiss and Jana Zimanová, 'K charakteristice deviantních a nedeviantních sexuálních delikventů', Kriminalistický sborník, 30, 2 (1986), 122-8.

92 Cf. Jaroslav Zvěřina and Jaroslava Pondělíčková, 'Psychopatologické nálezy u sexuálních agresorů', Československá psychiatrie, 80, 5 (1984), 298-302.

93 SOL was founded in Želiv in 1981, in Prague in 1986, etc. Slavoj Brichcín and Tereza Soukupová, 'Čtvrtstoletí bohnické sexuologie', XXIV. Bohnické sexuologické dny (Brno: CERM, 2012), 7-9.

94 Metodický list č, ' $1 / 1985$, hlavního odborníka pro obor psychiatrie MZ ČSR, o léčebných postupech při ochranném léčení sexuálních deviantů’, Československá psychiatrie, 82, 1 (1986), 60-3.

95 Ibid., 60.

96 The problem was (and still is) that 'not every sexual delinquent is forensically assessed because the need of such evaluation depends upon consideration of an investigator or other organs of criminal proceedings who are not always sufficiently informed' and that 'expert opinion is sometimes made by experts without psychiatric or sexological erudition': Petr Weiss, Slavoj Brichcín and Hana Fifková, 'Problémy ochranné léčby sexuologické', Česko-slovenská psychiatrie, 89, 5 (1993): 308. Due to a lack of forensic experts and inconsistence in the practice of expert opinion- making, the decision about the types of men who are forced to undergo SOL became ambiguous. Uncertainties persist to this day. Recently, a 60 -year-old man was reported to the police by some women who saw him on a remote road manipulating his pants - they suspected that he was masturbating. Yet, the man was changing the nappy he was using due to his persistently bleeding hemorrhoids. The police charged him with disorderly conduct and forensic experts subsequently diagnosed him with 'incomplete sexuality' and suggested SOL. Jan Kožnar, 'Ochranné sexuologické léčení, popírání deliktu a soudní znalecké posouzení,' XXIV. Bohnické sexuologické dny (Brno: CERM, 2012), 42-3.
} 
Despite the regime change in 1989, little changed in the treatment of sexual deviants in the following decades. Stability to the point of inertia came to characterise sexological practice. The only innovation we can track in the mid-1990s was an effort to establish a sexological ward with a proper therapeutic system in a prison in Kuřim (not in a psychiatric hospital as would be more usual). ${ }^{97}$ The goal was to already provide sexological treatment to deviant prisoners during their imprisonment, thus ensuring quicker re-socialisation (ie. the normalisation of their sexual behaviours and desires). Inmates would begin psychological treatment in prison and, after they served their sentence, they would be moved to a SOL institution where their time spent would be shorter because of the psychological work they had already done in prison, ultimately returning them to society in a shorter period of time. However, this aim was never fully realised due to the lack of professional staff who were to oversee the complex course of the treatment. ${ }^{98}$ The sexological ward in Kuřim thus became a rather preliminary/preparatory phase of medical SOL $^{99}$ and, as such, partly lost its original purpose. Therefore, we can conclude that sexological practice continued without any noticeable change during the entire decade of the 1990s.

Moreover, hardly anything has changed since the turn of the millennium. At its beginning, in 2002, the first monograph on the topic titled Sexual Deviations: Classification, Diagnosis and Treatment was published in the Czech Republic by Petr Weiss, one of the most famous sexologists in the country. The decades-long stagnation in sexological practice is underscored by the fact that in the chapters about the treatment of sexual deviation, Weiss builds primarily on old Czech sexological texts about research and treatment procedures (such as Nedoma's classic paper published in 1964). Weiss mentions with pride that the Czech sexological school is specific and virtually unique in its institutionalised treatment of sexual deviants thanks to 'independent sexological wards that were being established as part of major psychiatric hospitals since the 1970s'. ${ }^{100}$ According to Weiss, the Czech form of treatment is very effective and successful precisely as a result of this tradition. ${ }^{101}$ Curiously, this scholarly monograph has also been used directly in the treatment itself. Indeed, sexologists have presented it to SOL patients during their therapy in order to teach them about their diagnoses. ${ }^{102}$ The book was reprinted many times over without any fundamental changes; the last print edition came out under a different title in 2017: The Disorders of Sexual Preference. ${ }^{103}$ Whereas the name of the book was amended to be less judgemental and moralising, the text itself differs only slightly from the original version. Weiss has not even substantially revised the information about the treatment of sexual deviants, although he prepared the new version of the text after the CPT's visit and its criticism of Czech sexological treatment. Even though Weiss

\footnotetext{
97 Jiří Mezník, 'Zacházení se sexuálními delikventy ve výkonu trestu odnětí svobody ve věznici v Kuřimi', České vězeňství, 6, 3-4 (1998), 31-3.

98 Nowadays, many sexologists question practising any treatment in prison due to the fact that delinquents might not be fully open and speak honestly about their sexual crimes during imprisonment; indeed, this is problematic because effective therapy requires honesty and sincerity. Petr Weiss (ed.), Sexuologie (Praha: Grada, 2010); Zuzana Řeřichová, op. cit. (note 18).

${ }^{99}$ Ibid.

100 Petr Weiss, Sexuální deviace: klasifikace, diagnostika, léčba (Praha: Portál, 2002), 226.

101 As the criterion for the treatment's effectiveness, 'next to improving patients' quality of life', Czech sexologists deem the prevention of their 'criminal relapse' as the primary measurement. Weiss, op. cit. (note 3), 294. Thus, successful treatment is calculated based on the statistics of sexual recidivism. Ibid., 350.

102 Kapras, op. cit. (note 16).

103 Weiss, op. cit. (note 3).
} 
mentions the dispute with CPT in a few paragraphs, he still adheres to the view of Czech sexologists and does not acknowledge the criticism as substantiated. ${ }^{104}$

\section{A Missed Opportunity for a Turning Point: The International Expert Controversy}

In 2006, the European Committee for the Prevention of Torture and Inhuman or Degrading Treatment or Punishment visited the Czech Republic for the first time. ${ }^{105}$ During their trip, the CPT discovered that in one of the psychiatric hospitals 'there was no treatment protocol in force for sex offenders', ${ }^{106}$ nor were there sufficient legal norms or even updated professional guidelines for castration. Moreover, the expert group expressed doubts about the 'necessary condition' for the surgery: namely, the truly free and informed consent of the sex offender. According to the European experts, 'the concept of "free and informed" consent is hardly reconcilable with a situation in which the options open to an individual are extremely limited: surgical castration or possible indefinite confinement in a psychiatric hospital'. ${ }^{107}$

In the light of these findings, the expert group made more visits to the Czech Republic in 2008 and ad hoc in 2009, which appeared to them 'to be required' under 'the circumstances'. ${ }^{108}$ They intended to investigate the alleged abuse of therapeutic castration in the treatment of sex offenders. The Committee discovered that, at that time, the Czech Republic was flouting one of the highest numbers worldwide of sex offenders who have undergone the irreversible process of surgical castration - it was about ninety-four procedures in the preceding ten years. After visiting the relevant institutions, 'the CPT call[ed] upon the Czech authorities to bring to an immediate end the application of surgical castration in the context of treatment of sex-offenders'. ${ }^{109}$

However, the Czech Republic refused the European Committee's assessment and declared 'that this is a purely professional issue, and [the Czech Republic] does not consider the reasons specified by the Committee ... as sufficient and established'. ${ }^{110}$ Since the Czech Republic did not comply with the CPT's requirements, despite being asked repeatedly, an international debate began about the use of surgical castration as a treatment for sex offenders. For example, the IATSO stressed that 'most members of the committee who formulated the statute of IATSO and standards of care for sex offenders do not consider the surgical castration of sex offenders an appropriate treatment with respect to

\footnotetext{
104 Although Weiss advocates surgical castration again, he denounces hormonal castration at the same time when he explicitly states: 'The use of chemical castration, which can have many negative side-effects, is ethically questionable in cases that exchange long-term imprisonment for treatment with drugs; this can pose serious danger and damage to [the deviant's] health'. Ibid., 321. Thus, somewhat paradoxically, Weiss directs the same criticism against hormonal treatment that the CPT used against surgical castration.

105 The CPT pays expert visits to its member states and evaluates institutions (for example prisons or psychiatric hospitals) where people are deprived of their liberty. Thus, the CPTs main goal is to supervise compliance with human rights standards, and, as such, they uphold the rulings of the European Court of Human Rights. After every inspection, the Committee reports to the member state summarising in detail the shortcomings that should be corrected. The CPT's recommendations do not possess a binding power, but they remain highly regarded and are expected to be followed. However, the case of the Czech Republic has proved to be otherwise.

106 CPT, Report 2006, op. cit. (note 4), 46.

107 Ibid., 47.

108 CPT, Report 2008, op. cit. (note 4), 5.

109 Ibid., 18.

${ }^{110}$ Czech Government, op. cit. (note 5), 9.
} 
humane, dignified, compassionate and ethical therapy'. ${ }^{111}$ The human rights organisation, the Czech Helsinki Committee, also spoke out against surgical castration as a means of therapy. ${ }^{112}$ Indeed, since 2009 more and more expert groups have become involved in the discussion and negotiation of therapeutic castration.

Opposing networks of expertise clashed in the debate. On one side, Czech sexologists who are supported by the state emphasised the necessity to protect society from dangerous sexual delinquents. On the other, opponents from international oversight organisations stressed the need for a fundamental respect for human rights, the adherence to which does not allow a practice such as castration.

Although Czech sexologists considered the CPT's critique unfounded, they were nonetheless forced to respond under the pressure of the situation. Thus, since 2006, some changes have been introduced in the treatment of sex offenders. First, in 2007 the number of castrated men decreased sharply from an average of ten surgeries per year to three. ${ }^{113}$ Keeping the number of surgeries relatively low was made possible by some institutional changes; namely, the new practice of security detention (zabezpečovaci detence). Launched in 2009 in two prisons in Brno and Opava, it afforded the ability to contain 'uncooperative men' (eg. those unwilling to give consent for castration) in detention instead of holding them in SOL when they were not making any progress in their treatment. ${ }^{114}$

Security detention could be court-ordered for 'offenders who commit especially dangerous felonies, or who are not criminally responsible by reason of insanity, or whose free movement is unsafe for others, and in case of those for whom protective treatment would not result in a sufficient protection of society'. ${ }^{115}$ Importantly, detaining these offenders (including the security detention of sex offenders) lies within the jurisdiction of prison authorities. In contrast, protective treatment (again, including that of sex offenders) takes place in a medical institution under the auspices of medical professionals. This means that security detention is stricter and more restrictive of the inmate's freedom. However, the boundaries between security detention and protective treatment are permeable. For example, when SOL patients refuse to cooperate with the treatment (and/or disturb the therapeutic process), they can be sent into security detention. ${ }^{116}$ Thus, (the threat of) detention can ensure obedience in SOL patients and enforce their cooperation, serving a

111 IATSO cited in Vláda České republiky, Zpráva o stavu lidských práv v České republice v roce 2010, 21 July 2011, https://www.vlada.cz/assets/ppov/rlp/dokumenty/zpravy-lidska-prava-cr/Zprava-LP-2010_cz.pdf (accessed 18 August 2018), 84.

112 In the years 2008-13, Anna Šabatová was the head of the Czech Helsinki Committee. It should be noted that Šabatová, former dissident and one of the founders of Charter 77, was also a member of the CPT itself at the time (2008-11). In 2014, she was elected to the office of the Public Defender of Rights - ie. the Czech Ombudsman. Český helsinský výbor, Zpráva o stavu lidských práv v České republice za rok 2011, June 2012, http://www .helcom.cz/cs/zprava-o-stavu-lidskych-prav-v-cr-za-rok-2011/ (accessed 18 August 2018); https://www.ochran ce.cz/verejna-ochrankyne-prav-ombudsmanka/ (accessed 18 August 2018). Thus, she became the official state representative fighting against surgical castration.

113 Vláda ČR, op. cit. (note 111), 85.

114 As doctor Kapras from the sexological ward in Horní Beřkovice mentioned: 'We had a serious sadistic killer in here who was not cooperating at all. He had to be in a closed ward, therefore he was not attending therapy and he kept refusing castration. So, we got stuck in terms of therapy because, really, we had to hold him in here for the safety of society but we were unable to cooperate with him. It was deliverance for him when the security detention was established'. Kapras, op. cit. (note 16).

115 Slavoj Brichcín, 'Soudní sexuologie', in Petr Weiss (ed.), Sexuologie (Praha: Grada, 2010), 540-1.

116 Of course, if such an inmate in detention 'honestly' chooses to cure himself again, he can go back in SOL (if the court allows it). 
coercive function. When dangerous offenders do not ask for castration (their asking being the sine qua non for the procedure to be undertaken), and thus cannot be released from protective treatment, they can be transferred to detention. In any case, the disciplining and punitive power of sexology is strengthened as a result. That is, the temporary decrease in the number of castrated men was caused by moving sex offenders from the medical jurisdiction back to the prison authorities.

In 2010, a directive titled 'Recommended procedure for surgical castration in connection with paraphiliac-motivated sexual offences' (Doporučený postup při provádění chirurgické kastrace $v$ souvislosti s parafilně motivovanými sexuálními delikty) came into force, which specified the whole procedure of therapeutic castration for the first time since its legalisation (including its contraindications, treatment alternatives, possible side-effects, etc.). ${ }^{117}$ The directive of the Ministry of Health was further updated in $2012,{ }^{118}$ when a new law 'On specific health services' ${ }^{119}$ was passed, which tightened the prerequisites for castration by: establishing a minimum age limit of at least twentyfive; introducing a new condition that at least one sexual offence must be committed (so that men without prior convictions for sex crimes could no longer be castrated); requiring that expert approval state both sexual deviance and high probability that a violent sexually motivated crime will be committed again; and banning the surgical procedure from being 'performed in medical establishments of the Prison Service and to the people remanded in custody and imprisonment ... and to the patients deprived of legal capacity'. ${ }^{120}$ The relationship between the state and the experts tightened as a result of these laws and directives. Specifically, the expert approval now needed to be expressed by a ministerial commission where a 'health-care practitioner employed by the state at the Ministry of Health' would sit next to a sexologist, a psychiatrist, a clinical psychologist, a urologist and a health care lawyer. ${ }^{121}$

Most of the changes laid out by the directive related to castration as a treatment since it was the main problem in the CPT's eyes. Minor adjustments were also made in the laws regulating SOL, whose maximum duration was now limited to two years with the possibility of court extension. ${ }^{122}$ However, new legislation was predominantly formal and did not have any significant impact on SOL. Since sexological treatment usually lasts longer than two years, the new directive did not really limit anything. According to sexologists, it merely constitutes a senseless administrative duty to extend SOL every two years, which happens routinely and thus does not actually improve the lives of SOL patients. ${ }^{123}$

Tasked by the Ministry of Health, the Czech Sexological Society conducted research in 2015 focusing on 'The results of therapeutic castration of paraphilic sexual delinquents' (Výsledky terapeutické kastrace u parafilních sexuálních delikventů). ${ }^{124}$ The goal was to

117 'Doporučený postup při provádění chirurgické kastrace v souvislosti s parafilně motivovanými sexuálními delikty', Věstník Ministerstva zdravotnictví, 1 (2010), 24-7.

118 'Doporučený postup při provádění kastrací v souvislosti s parafilně motivovanými sexuálními trestnými činy', Věstník Ministerstva zdravotnictví, 5 (2012), 2-6.

119 'Zákon č. 373/2011 Sb., o specifických zdravotních službách’ Sbírka zákonů České republiky, 131 (2011).

120 Ibid., $\S 20$.

121 Ibid., $\S 18$.

122 Švarc, op. cit. (note 17).

123 Ibid.

${ }^{124}$ Jaroslav Zvěřina, Petr Weiss and Martin Hollý, Výsledky terapeutické kastrace u parafilních sexuálních delikventů, 16 February 2015, https://www.mzcr.cz/dokumenty/vysledky-terapeuticke-kastrace-u-parafilnich-s exualnich-delikventu_10012_1045_3.html (accessed 18 August 2018). 
examine fifty castrated men, ${ }^{125}$ evaluate the positives and negatives of the surgical method of treatment, and thus provide a basis for the government to decide whether to change legislation or even to ban castration completely. The authors of the study primarily quoted sexological papers published during the 1970s and 1980s and, after analysing the responses of their research subjects, arrived at the conclusion that the research has 'shown the high efficacy of the treatment method in terms of the substantial reduction of specific recidivism of sexual delinquency'. ${ }^{126}$ The majority of respondents, $88 \%$, confirmed their voluntary participation in castration, and $60 \%$ of them said that they would undergo it again. In the light of these findings, authors concluded that: 'current legislation on castration ... meets every expert and ethical aspect. The surgical operation should not be excluded from our treatment arsenal. ${ }^{127}$ And the government obliged. ${ }^{128}$

In July 2016, the Czech government reversed its course of decreasing the number of castrations and supported a new law which extends the range of sexual deviants eligible for the procedure. As Svatopluk Němeček, then the Minister of Health, stated: 'The results of the study clearly prove that it is a more effective method than anything else. ... When the patients feel that they are not able to handle their problem and could do something they would regret for the rest of their life, I do not see any reason why we wouldn't make it [surgical castration] available to them. ${ }^{129}$ The minimum age limit was lowered to twenty-one years because, 'from the medical point of view', the previous age limit of twenty-five years 'had no justification' ${ }^{130}$ and, conversely, 'the limit of twenty-one years is sufficient with respect to the intellectual maturity of an individual common for this age'. ${ }^{131}$ Concurrently, the condition of having to have committed a sexually motivated crime was removed from the law, as the experts, together with the government, tried to avoid 'a paradoxical situation in which someone commits a violent crime after receiving a negative decision from the Ministry of Health that his castration was rejected because "he has not committed a violent sexually motivated crime yet". ${ }^{132}$ This new law was ratified on 1 November 2017. It is reasonable to expect that the amount of castrations may increase in the future.

\footnotetext{
125 The sexologists used two types of questionnaires. First, the respondents filled-in the answers with the help of their attending physicians and, second, they were asked to share more intimate information in a more detailed survey that they could send anonymously by mail. (The idea was that the anonymity would break through any potential shyness or reluctance in responding to sensitive topics, and thus lead to more valid data.) The questions were focused on the patient's reasons for undergoing surgical castration and its effect; the effect was evaluated on the basis of recidivism in sexual delinquency and any actual occurrences of somatic and/or psychological problems that can develop as a consequence of hormonal changes in the organism. More specific questionnaires also asked questions about the patients' decision-making process when deciding to undergo the surgery; they also looked for an evaluation (with a timespan ranging from two to twenty-four years since castration) and a subjective assessment of the impact the procedure had on the respondent's own health and social life: Ibid.

126 Ibid., 29.

127 Ibid.

${ }^{128}$ It was the same left-wing government, under the leadership of Prime Minister Bohuslav Sobotka, which had tasked the sexological experts to conduct the research. It is interesting that, although there have been many changes in the composition of the government since the beginning of the dispute with the CPT (as the right-wing parties ODS or TOP 09 and also the left-wing ČSSD were in charge during this period), the politicians' viewpoint on castration has remained the same all along (and in accordance with the Czech sexological discourse).

129 Svatopluk Němeček cited in Pavel Cechl, 'Stát umožní kastrovat více deviantů', Týden, 46 (2015), 21.

130 Petr Weiss cited in Hana Válková, Podmínky pro kastraci se změní: Nebude se čekat na znásilnění či vraždu, 9 July 2014, https://zpravy.idnes.cz/novela-zakona-kastrace-podminky-da5-/domaci.aspx?c=A140709_135942_ domaci_hv (accessed 18 August 2018).

131 Štěpánka Čechová (then the spokesman for the ministry) cited in Pavel Cechl, op. cit. (note 129).

132 Ibid.; Ministerstvo zdravotnictví ČR, op. cit. (note 6).
} 


\section{Conclusion}

In state-socialist Czechoslovakia, new kinds of people emerged - those who deviated sexually and were eventually viewed as in need of the ultimate treatment, that of surgical castration. These sexual deviants, delinquents and sexual aggressors, as they came to be named, were classified through the reshuffling matrices of expertise where sexologists achieved the most decisive voice. In the Czech Republic today, it continues to be the sexologists who wield superior knowledge over the jurisdiction of sexual deviance. This expertise has been decades in the making. It formed in the 1960s after it had been scarce and rather haphazard in the preceding decade. The first turning point occurred in the mid-1960s when three avenues of treatment were explored: hormonal downturn complete with psychotherapy; castration; and protective treatment. While the leading sexologists first argued forcefully for the hormonal treatment and against surgical castration, over time they became persuaded that a method was called for, which would not depend on the deviant's continual willingness to take medication and participate in out-patient therapy. While surgical castration was legalised in 1966, it did not constitute the main form of treatment until the mid-1970s. Then, another turning point took place when the first sexological ward in a psychiatric hospital opened that was specifically designed for recidivist sexual aggressors, ie. heterosexual men exhibiting aggressive behaviour towards women who were mostly unknown to them. The opening of this ward was made possible by the ministerial directive on protective treatment. The state's continued attention and support for sexologists developed a trajectory that targeted sexual delinquents who were diagnosed with pathological sexual aggression. This trajectory contained only slight modifications that were not thwarted by the repeated criticism of various expert international bodies.

It is worth noting that the trajectory, lasting to this day, commenced during the time of Normalization, the communist regime's period of consolidation after the Prague Spring and its violent suppression. It was at this time of heightened attention to normalcy and deviation from the sanctioned forms of conduct that sexologists linked with the state. Sexologists needed their expertise recognised and they very much appreciated the extended jurisdiction that now included a growing category of sexual delinquency. It became the SOL patients of the Normalization period and beyond, for whom 'normal' coupledom and family could be within reach, albeit with a little expert help. And sexologists took it upon themselves to normalise these sexual deviants. If the help was not bearing fruit, or if the level of aggression (and subsequent danger to society) was seen as high, sexologists were likely to prescribe surgical castration.

We have shown how the situation of men committing sexually motivated offences changed in Czechoslovakia/Czech Republic over time as a result of the changes within sexological expertise that were facilitated by a shift in the state's priorities. Two interconnected processes propelled the increasing rates of surgical castration: both establishing a category of people in need of such a treatment, and institutionalising a form of appropriate treatment for such people. Thus, a powerful matrix came into existence in the Czech Republic, reproducing and entrenching processes leading inevitably to the surgical castration of sex offenders.

Our research underscores the continuity in medical practice despite the regime change in 1989. Unlike some previous studies that identify continuities in rather fringe medical (and non-medical) disciplines and practices, we document here a lasting trajectory in sexology that became mainstream over time. With regard to previous scholarship on 
state-socialist Czechoslovakia, we argue that it was the medical mainstream, understood as inescapable from the point of view of those identified as its patients, that developed and sustained disciplining and punitive features. Thus, Czech sexologists who continue to be supported by the Ministry of Health and the state in their unparalleled approach to sexual offenders can unwaveringly state: 'We won't ban castrating pervs despite what Europe might think!'133

133 Naďa Adamčíková and Marie Königová, 'Kastrace úchylů vzdor Evropě nezakážeme’, Právo, 14 (2015), 1,3 . 